\title{
Spatio-temporal variability of the isotopic input signal in a partly forested catchment:
}

\section{Implications for hydrograph separation}

C. Cayuela ${ }^{1, *}$, J. Latron ${ }^{1}$, J. Geris ${ }^{2}$, P. Llorens ${ }^{1}$

${ }^{1}$ Institute of Environmental Assessment and Water Research (IDAEA-CSIC), Jordi Girona 1826, 08034 Barcelona, Spain.

2 Northern Rivers Institute, School of Geosciences, University of Aberdeen, Aberdeen,

Scotland, United Kingdom

*Corresponding author

carles.cayuela@idaea.csic.es (C. Cayuela)

Running head: Spatio-temporal variability of precipitation on hydrograph separation

Keywords: Stable water isotopes; Catchment input signal; Spatio-temporal variability; Isotope hydrograph separation; Uncertainty; Vallcebre research catchments

\footnotetext{
This article has been accepted for publication and undergone full peer review but has not been through the copyediting, typesetting, pagination and proofreading process which may lead to differences between this version and the Version of Record. Please cite this article as doi: 10.1002/hyp.13309
} 


\section{ABSTRACT}

The isotopic composition of precipitation ( $\mathrm{D}$ and ${ }^{18} \mathrm{O}$ ) has been widely used as an input signal in water tracer studies. Whereas much recent effort has been put into developing methodologies to improve our understanding and modelling of hydrological processes (e.g. transit-time distributions or young water fractions), less attention has been paid to the spatio-temporal variability of the isotopic composition of precipitation, used as input signal in these studies. Here, we investigated the uncertainty in isotope-based hydrograph separation (IHS) due to the spatio-temporal variability of the isotopic composition of precipitation. The study was carried out in a Mediterranean headwater catchment $\left(0.56 \mathrm{~km}^{2}\right)$. Rainfall and throughfall samples were collected at three locations across this relatively small catchment and stream water samples were collected at the outlet. Results showed that throughout an event, the spatial variability of the input signal had a higher impact on hydrograph separation results than its temporal variability. However, differences in IHS determined pre-event water due to the spatio-temporal variability were different between events and ranged between 1 and 14\%. Based on catchmentscale isoscapes, the most representative sampling location could also be identified. This study confirms that even in small headwater catchments, spatio-temporal variability can be significant. Therefore, it is important to characterise this variability and identify the best sampling strategy to reduce the uncertainty in our understanding of catchment hydrological processes. 


\section{INTRODUCTION}

Much of our understanding of the hydrological process relies on the relationship between precipitation and a predictor (e.g. runoff, soil moisture, etc.). Precipitation is indeed the main input driving many if not most models of hydrological processes (Seibert and McDonnell, 2002; McDonnell and Beven, 2014). However, while we know that precipitation varies greatly in time and even over short distances in space (Goodrich et al., 1995; Girons Lopez et al., 2015; Vieux, 2016), uniformity is often still assumed for small areas. This assumption applies not only to the precipitation amount, but also to its isotopic composition (D and ${ }^{18} \mathrm{O}$ ), which has become a common tool in tracer hydrological investigations (McGuire and McDonnell, 2015). As such, this could have serious implications for our understanding of a catchment functioning.

At a specific location, the isotopic composition of precipitation is the result of the combination of multiple and complex processes. These processes have been studied and described over the years, particularly in large-scale studies (i.e. Dansgaard, 1964; Smith et al., 1979; AraguásAraguás et al., 2000; Seeger and Weiler, 2014; Bowen and Good, 2015). These studies concluded that major factors controlling the isotopic composition of precipitation include its vapour source, air mass trajectory, and fractionation that occurs as water evaporates into the air mass and during precipitation formation. Based on correlation or geostatistical relationships, spatially continuous maps of the isotopic composition of precipitation ("isoscapes") have often been constructed from long-term mean annual or monthly observations (Bowen et al., 2009). However, precipitation is greatly influenced by geographic and temporal variations, most of which are not captured when analysed on a larger scale. For example, higher elevation landforms usually cause disproportionately high rainfall on their windward side, a rain-out of heavier isotopes and lower evaporation rates of falling raindrops that lead to a more depleted precipitation (Dansgaard, 1964). Siegenthaler and Oeschger (1980) and Holdsworth et al. (1991) reported that elevation effects varied from -0.15 to $-0.5 \%$ per $100 \mathrm{~m}$ increase in 
elevation for ${ }^{18} \mathrm{O}$, and from -1 to $-4 \%$ o for D. Moreover, within a rainfall event, changes in air mass temperature can modify significantly the isotopic composition of precipitation. As such, higher rainfall intensities, coinciding with maximum air mass lift and cooling, result in more depletion (Dansgaard, 1964; Celle-Jeanton et al., 2004). Furthermore, the isotopic composition of rainfall can also be affected by canopy interception processes that, in general, lead to more enriched net precipitation (sum of throughfall and stemflow inputs) than open rainfall, although depletion is also possible (Allen et al., 2017). The isotopic shift produced in the canopy is mainly due to evaporation of falling water (Saxena, 1986), equilibrium exchange between vapour and liquid (Friedman, 1962) and the retention in the canopy of the last portion of precipitation (Dewalle and Swistock, 1994). Therefore, to better understand rapid hydrological responses (event scale processes), spatial and temporal isotopic variations at smaller scales need to be taken into account (Von Freyberg et al., 2017; Allen et al., 2018).

Over the last few decades, isotope-based hydrograph separation (IHS) has been widely used in hydrology as a useful tool to gain insights into catchment runoff processes (i.e. Sklash et al., 1976; Pearce et al., 1986; McDonnell et al., 1990; Kubota and Tsuboyama, 2003; Fischer et al., 2017). These, among many other hydrological studies that aim to clarify water origin and movements, relied on the conservative behaviour of water stable isotopes and used $\mathrm{D}$ and ${ }^{18} \mathrm{O}$ as tracers. The common practice for small headwater catchments $\left(<10 \mathrm{~km}^{2}\right)$ is to sample rainfall at one location and assume that rainfall amount and its isotopic composition are uniform (McDonnell and Beven, 2014; Fischer et al., 2017). Nevertheless, the few studies that explored the effect of different sampling locations or temporal resolutions actually found large differences in hydrograph separation. For instance, Lyon et al. (2009) found differences in preevent water larger than $50 \%$ when using rainfall collected at different locations within a catchment. Likewise, Fischer et al. (2017) observed that the spatial variability of rainfall was almost as large as its temporal variability in its isotopic composition, and that it varied from 
event to event, producing differences up to $60 \%$ in the pre-event water contribution. In addition, Kubota and Tsuboyama (2003) used throughfall instead of rainfall as input signal and found differences that ranged between 5 and $10 \%$ in pre-event water contributions. Finally, Von Freyberg et al. (2017), by comparing results of different sampling frequencies, found that sampling at time intervals longer than $3 \mathrm{~h}$ resulted in an underestimation of the event-water fraction. However, studies in small headwater catchments, where effects of elevation, forest cover and both spatial and temporal variations are all evaluated simultaneously, are still required. This is particularly relevant in areas where factors like high climate seasonality, spatially distributed forest cover or temporally varying runoff generation processes add even more complexity. Such understanding would also be needed towards finding effective sampling strategies in order to decrease the spatio-temporal uncertainties in the understanding of IHS-deduced hydrological processes.

Here, we analyse the spatio-temporal variability of precipitation in a small, partly forested Mediterranean headwater catchment in order to address the following questions: i) what is the spatio-temporal variability in the isotopic composition of rainfall and its relation to elevation and forest cover? ii) what is the uncertainty associated with isotope-based hydrograph separation due to the spatio-temporal variability of rainfall? and iii) how can we identify the best sampling strategy to obtain a representative input signal for the entire catchment? Answers to these questions will ultimately improve the understanding of dominant hydrological processes in seasonal mid-latitude small headwater catchments.

\section{METHODOLOGY}

\subsection{Study area}

The study was conducted in the Can Vila catchment $\left(0.56 \mathrm{~km}^{2}\right)$ located within the Vallcebre research area (NE Spain, $\left.42^{\circ} 12^{\prime} \mathrm{N}, 1^{\circ} 49^{\prime} \mathrm{E}\right)$. The catchment drains into the River Llobregat, which supplies most of the surface water for the city of Barcelona. The climate is Sub- 
Mediterranean, characterised by a marked water deficit in summer. Mean annual temperature (1989-2013) is $9.1 \pm 0.67^{\circ} \mathrm{C}$, mean annual precipitation is $880 \pm 200 \mathrm{~mm}$ and mean annual evapotranspiration, calculated by the method of Hargreaves and Samani (1982) is $823 \pm 26$ $\mathrm{mm}$. Precipitation is seasonal, with autumn and spring usually being wetter seasons, and summer and winter often drier. Summer rainfall is characterised by intense convective events, while winter precipitation is caused by frontal systems, with snowfall accounting for less than $5 \%$ of precipitation (Latron et al., 2010a, 2010b; Llorens et al., 2018).

In the past, most of the hillslopes were deforested and terraced for agricultural purposes (Poyatos et al., 2003). However, at present, the catchment is mostly covered by Scots Pine (Pinus sylvestris L.) forests (58.3\%) that cover all elevations. In addition, grasslands $(31.9 \%)$ and shrubs (4.1\%) are also found within the catchment (Figure 1a). Despite the human impact on the landscape, the primary stream network in the catchment is mostly natural: it is one to three meters wide and not very deeply incised. Stream runoff responses have a clear seasonal pattern, with an alternation between wet periods, when the catchment is hydrologically responsive and produces larger runoff coefficients and gentle recessions, and dry periods, when the catchment is much less reactive to precipitation and produces low runoff coefficients (Latron et al., 2008). The high spatio-temporal variability of the hydrological responses is related to the extent of saturated areas, that are very relevant for runoff generation in the catchment (Latron and Gallart, 2007). On average, the stream dries out in summer once every two years for a period ranging from 15 to 40 days (Latron et al., 2010b).

The catchment area is almost entirely situated on clayey bedrock, with soils predominantly of silt-loam texture. Soil depth is variable, mainly because of the changes induced by terracing, with typical depth between 0.5 and $3 \mathrm{~m}$. Topsoil is rich in organic matter, but this decreases with increasing depth from $15.3 \%$ in the top layer to $0.33 \%$ in the deepest one. In addition, soils are well-structured and with high infiltration capacity, although this decreases rapidly 
with depth (Rubio et al., 2008). The altitude of the catchment ranges between 1,108 and 1,462 $\mathrm{m}$ a.s.l. (Figure $1 \mathrm{~b}$ ). Slopes vary between 0 and $20 \%$ in most of the catchment, except in its upper part, characterised by a limestone cliff with slopes steeper than $40 \%$.

\subsection{Hydrometric monitoring}

Hydrometric monitoring was conducted from May 2015 to May 2016. Rainfall was measured at three locations representing $75 \%$ of the area-proportional elevation range (Figure 1b): VH (1,115 $\mathrm{m}$ a.s.1.), $\mathrm{VT}_{\mathrm{rf}}(1,193 \mathrm{~m}$ a.s.l.) and $\mathrm{VM}$ (1,287 $\mathrm{m}$ a.s.1.). These involved $0.2 \mathrm{~mm}$ tippingbucket rain gauges (Casella CEL, Casella, UK), which were all placed in open areas and located $1 \mathrm{~m}$ above the ground. Throughfall was measured under a Scots pine forest ( $\left.\mathrm{VT}_{\mathrm{tf}}\right)$ by 200.2 mm tipping-bucket rain gauges (Davis Rain Collector II, Davis Instruments, USA), distributed to cover all ranges of canopy cover, which were previously determined by hemispherical photographs (Llorens and Gallart, 2000). Finally, runoff data were obtained from the catchment outlet gauging station ( $\mathrm{VH}$ ) equipped with a $90^{\circ} \mathrm{V}$-notch weir and a water pressure sensor. Runoff was determined using established stage discharge rating curves, calibrated by manual discharge measurements. All hydrometric data were stored every 5 minutes by dataloggers (DT 50/80 Datataker, Datataker Inc., USA).

\subsection{Sampling design}

For the same period, rainfall, throughfall and stream water samples were collected for isotope analyses on an event basis by bulk and sequential collectors. Rainfall and throughfall bulk collectors consisted of plastic funnels (130 mm diameter) positioned $50 \mathrm{~cm}$ above ground and connected to a 1 litre plastic bin. Sequential collectors of stream water and rainfall consisted of plastic funnels (340 mm diameter) connected to an automatic water sampler (24 500-ml bottles, ISCO 3700C). To minimize evaporation, both bulk and sequential collectors were buried beneath the soil surface and connected to the funnels by looping drainage tubes. 
Open rainfall was collected bulkily and sequentially (every $5 \mathrm{~mm}$ of rainfall) at the top part $(\mathrm{VM})$ and at the outlet of the catchment (VH). Throughfall was collected in the forest stand $\left(\mathrm{VT}_{\mathrm{tf}}\right)$ with 10 bulk collectors representative of all ranges of canopy cover (Cayuela et al., 2018). In addition, one sequential sampler collected throughfall samples every $5 \mathrm{~mm}$ of rainfall. The isotopic composition of rainfall at $\mathrm{VT}_{\mathrm{rf}}$ was calculated by means of the linear regression between elevation and $\delta \mathrm{D}$ (using VM and VH samples for each event). Results were compared and validated with 7 samples of rainfall collected at $\mathrm{VT}_{\mathrm{rf}}$ during the study period. The regression parameters showed a good fit between estimated and real values (slope 1.01, intercept 1.06 and $\left.r^{2}=0.99\right)$.

Finally, stream water samples were collected at VH by two automatic water samplers (24 1,000-ml bottles, ISCO 3700C). Each collector sampled stream water at different time frequencies. One sampled once every 12 hours and the other sampled at higher resolution intervals during events to ensure the sampling of the rising and falling limb of the hydrograph. In addition, a manual stream water sample was collected weekly during days of data and sample collection.

\subsection{Isotope analysis}

All water samples were analysed at the Scientific and Technological Services of the University of Lleida, using a Cavity Ring-Down Spectroscopy Picarro L2120-i isotopic water analyser (Picarro Inc., USA). The precision of the measurements, based on the repeated analysis of four reference water samples, was $<0.1 \%$ and $<0.4 \%$ o for $\delta^{18} \mathrm{O}$ and $\delta \mathrm{D}$, respectively. All isotope data are expressed in terms of $\delta$-notation as parts per mil (\%o) relative to Vienna Standard Mean Ocean Water (VSMOW).

\subsection{Catchment-scale isoscapes}


Finer-scale isoscapes were constructed for events in which IHS was calculated. The isoscapes represented the catchment-scale isotopic input signal for different time-intervals within the event. The interpolation was based on a 2-meter resolution digital elevation model (DEM), the point scale precipitation amount (5 min data from the rain gauges) and $\delta \mathrm{D}$ values in $\mathrm{VH}, \mathrm{VM}$ and $\mathrm{VT}_{\mathrm{rf}}$ (samples every $5 \mathrm{~mm}$ of rainfall). Among predictor variables (elevation, latitude and longitude), elevation was used to estimate $\delta \mathrm{D}$ at each pixel of the DEM. Afterwards, for each elevation, the effect of the forest cover was incorporated to pixels with forest. Thus, for each event, time interval and pixel with forest, the amount of precipitation and its isotopic signature were modified according to canopy interception losses and isotopic differences between throughfall $\left(\mathrm{VT}_{\mathrm{tf}}\right)$ and rainfall $\left(\mathrm{VT}_{\mathrm{rf}}\right)$. Finally, an incremental weighted mean catchment-scale isotopic input signal was calculated for each time interval (McDonnell et al., 1990). The resulting interpolation was then evaluated by comparing the estimated $\delta \mathrm{D}$ values at $\mathrm{VH}, \mathrm{VM}$ and $\mathrm{VT}_{\mathrm{tf}}$, with the measured values. Regression parameters showed a good fit (slope 0.99, intercept 0.11 and $r^{2}=0.99$ ).

With this information, three scenarios were analysed for the catchment-scale isotopic input signal: i) a catchment with the current land cover, with $58 \%$ of forest (Scenario 1 ) that resulted from the original interpolation, ii) a catchment completely covered by forest (Scenario 2), where all pixels of the DEM had to be forest, and iii) a completely deforested catchment (Scenario 3), where all pixels were considered grassland. From these scenarios we hypothesize that the catchment-scale input signal calculated for the actual land uses (Scenario 1) was the most representative input signal for the entire catchment. Scenarios 2 and 3 represent a hypothetical catchment input signal in which precipitation measurements and isotopic sampling would take into account the elevation effect, but only under forest (Scenario 2) or in an open area (Scenario 3).

\subsection{Data analysis and isotope-based hydrograph separation}


Rainfall events were defined as periods with more than $1 \mathrm{~mm}$ of precipitation. To ensure canopy dryness between events, the inter-event period was set to be at least 6 hours during the day and 12 hours during the night (Llorens et al., 2014). Following Latron and Gallart (2007), runoff event duration as well as stormflow depth and coefficient were derived for each rainfallrunoff event selected, using the "constant slope" method of Hewlett and Hibbert (1967) with a modified slope value of $1.381 \mathrm{~s} \mathrm{~s}^{-1} \mathrm{~km}^{-2} \mathrm{day}^{-1}$, once a discharge increment in the stream higher than $5.61 \mathrm{~s}^{-1} \mathrm{~km}^{-2}$ was identified.

In total, the spatio-temporal variability of the input signal was analysed for 29 rainfall events. For each event, differences between the isotopic composition of bulk samples of rainfall at $\mathrm{VM}$, rainfall at $\mathrm{VH}$ and a volume-weighted mean of throughfall in $\mathrm{VT}_{\text {th }}$ were analysed by a linear mixed model (LMM) with repeated-measurement structure. In the model, elevation, rainfall amount, rainfall interception loss and season were included as covariate fixed effects, and the factor "event" was used as a random effect. Isotope-based hydrograph separation (IHS) was performed only for those 7 runoff events that met the following two criteria: (1) enough runoff was generated at the outlet to collect several samples (more than 4) during the flood, and (2) the required assumptions for IHS proposed in Pearce et al. (1986) and Sklash et al. (1986) were all met. The isotope-based hydrograph separation used two components to quantify the contribution of pre-event ("old") and event ("new") water into the stream during the duration of the runoff event, using different input signals. The pre-event water contribution was calculated by solving the mass balance equations (Eqs. (1) and (2)) (Pinder and Jones, 1969).

$$
\mathrm{Q}_{\mathrm{S}}=\mathrm{Q}_{\mathrm{E}}+\mathrm{QPE}_{\mathrm{PE}}
$$

$\mathrm{C}_{\mathrm{S}} \mathrm{Q}_{\mathrm{S}}=\mathrm{C}_{\mathrm{E}} \mathrm{Q}_{\mathrm{E}}+\mathrm{C}_{\mathrm{PE}} \mathrm{Q}_{\mathrm{PE}}$ 
where $\mathrm{Q}$ is discharge, $\mathrm{C}$ refers to the isotopic signature, and the subscripts $\mathrm{S}, \mathrm{PE}$ and $\mathrm{E}$ indicate the stream, the pre-event water and the event water, respectively. Equations (1) and (2) are used to find the contribution of the pre-event water in the streamflow (Eq. (3)).

$\mathrm{X}=\left(\mathrm{C}_{\mathrm{S}}-\mathrm{C}_{\mathrm{E}}\right) /\left(\mathrm{C}_{\mathrm{S}}-\mathrm{C}_{\mathrm{PE}}\right)$

where $\mathrm{X}$ is the ratio of $\mathrm{QPE}_{\mathrm{PE}} / \mathrm{Q}_{\mathrm{s}}$.

The isotopic signature of the stream sample prior to the event was used as the pre-event water component. Nine different input signals were used as event water: rainfall at the top of the catchment (VM) (bulk and sequential); rainfall at the bottom of the catchment (VH) (bulk and sequential); throughfall at the centre of the catchment (VT $\left.\mathrm{VT}_{\mathrm{tf}}\right)$ (bulk and sequential); and the catchment-scale input signal for the three proposed scenarios. $\delta \mathrm{D}$ for sequential samples of rainfall and throughfall was adjusted by means of the incremental mean technique (McDonnell et al., 1990), which took into account the temporal variability of the rainfall amount.

Uncertainty in the hydrograph separation due to the variability of the input signal was analysed with a Monte Carlo approach, following an adaptation by Bazemore et al. (1994). For each event and time step, the Monte Carlo approach solved equation (3) 50,000 times. The isotopic composition of the input signal was randomly chosen within the range of its spatial variability, which was obtained by calculating normal distributions of the isotope signature for each time step. Finally, 95\% confidence intervals were calculated.

\section{RESULTS}

\subsection{Isotopic composition of rainfall, throughfall and streamflow}

Total rainfall during the studied period ( 12 months) was 1,102 mm. Rainfall amount from the 29 analysed rainfall events ranged between 3 and $129 \mathrm{~mm}$ and accounted for $71 \%$ of total rainfall. Total runoff was $379 \mathrm{~mm}$, with the seven events selected for IHS accounting for $36 \%$ of total runoff (Figure 2). Nevertheless, as seen in Table 1, the hydrological response of these 
events was representative of the different types of runoff responses that occurred in the catchment during the period studied.

The isotopic composition of rainfall at VM ranged from -128.62 to $-6.02 \%$ for $\delta \mathrm{D}$ and from 17.04 to $-2.12 \%$ for $\delta^{18} \mathrm{O}$. At $\mathrm{VH}$, the isotopic composition of rainfall ranged from -125.82 to $-5.84 \%$ for $\delta \mathrm{D}$ and from -17.03 to $-2.05 \%$ for $\delta^{18} \mathrm{O}$. On the other hand, the isotopic composition of throughfall in $\mathrm{VT}_{\mathrm{tf}}$ ranged from -123.64 to $-6.85 \%$ for $\delta \mathrm{D}$ and from -16.44 to $-2.3 \%$ o for $\delta^{18} \mathrm{O}$. Significant differences were found between the isotopic composition of summer and winter rainfall $\left(\mathrm{F}_{1,56}=14.88 ; p<0.01\right)$, whereby rainfall was more enriched during summer and more depleted during winter. The median of stream water was $-46.97 \%$ for $\delta \mathrm{D}$ and $-7.29 \%$ o for $\delta^{18} \mathrm{O}$ (Figure 2). The inter-quartile ranges were -40.65 to $-56.34 \%$ and -6.31 to $-8.40 \%$, respectively. For conciseness, further data analysis is shown for $\delta \mathrm{D}$ only. Even though the choice of isotope may also slightly influence hydrograph separation results (Lyon et al., 2009), evaluating the uncertainty related to that is beyond the scope of this work. Moreover, covariation between Oxygen-18 and Deuterium suggested that fractionation due to nonequilibrium factors was negligible $\left(\mathrm{r}^{2}=0.97, p<0.05\right)$. Figure 2 shows the rainfall and runoff time series for $\delta \mathrm{D}$, including the spatial variability observed in rainfall.

\subsection{Elevation effect}

Rainfall measured in the upper part of the catchment (VM) was significantly more depleted $\left(F_{1,28}=14.96 ; p<0.01\right)$ than in the lower part $(\mathrm{VH})$ (Figure 3$)$. The mean change in $\delta \mathrm{D}$ was $1.25 \%$ per $100 \mathrm{~m}$ increase in elevation. This decreasing trend with elevation was observed for 24 of the 29 analysed events. In addition, at the event scale and during the entire period under study, depletion at the upper part of the catchment coincided (Figure 3$)$ with more rainfall $\left(F_{1}\right.$, $26=4.97 ; p<0.05)$, with no statistically significant differences between seasons $\left(F_{1,26}=2.08\right.$; $p=0.16$ ). Mean event rainfall was only $2 \mathrm{~mm}$ greater at $\mathrm{VM}$ than at $\mathrm{VH}$, representing $8 \%$ more rainfall at VM. However, the range of the differences was highly variable depending on the 
rainfall event. For example, event 19, with more rainfall and greater intensity than the average (more than $100 \mathrm{~mm}$ of rainfall in under 24 hours), had the highest rainfall amount difference $(23 \mathrm{~mm})$ between the upper and lower parts of the catchment. Overall, during the period studied $66 \mathrm{~mm}$ more rainfall was measured at VM.

\subsection{Forest cover effect}

Mean throughfall collected below the forest canopy was lower than the volume of open rainfall (Figure 4). Greater variability in the amount of throughfall was found for rainfall events under $20 \mathrm{~mm}$, for which loss due to canopy interception ranged between 10 and $50 \%$ of the open rainfall. For larger rainfall events $(>20 \mathrm{~mm})$, however, differences in volume between open rainfall $\left(\mathrm{VT}_{\mathrm{rf}}\right)$ and throughfall $\left(\mathrm{VT}_{\mathrm{tf}}\right)$ were reduced, with canopy interception between 0 and $10 \%$.

The mean isotopic composition of throughfall was, in general, heavier than open rainfall (Figure 4), with a mean enrichment of $2.95 \%$, although differences tended to decrease for events larger than $20 \mathrm{~mm}$. No relationship could be found between the isotopic composition of throughfall and rainfall interception losses $\left(F_{1,26}=0.41 ; p=0.53\right)$. Nor were there differences between seasons $\left(\mathrm{F}_{1,26}=0.31 ; p=0.58\right)$, although mean isotopic differences appeared slightly higher during the winter season.

\subsection{Catchment-scale isoscapes for hydrograph separation}

Figure 5 shows the different bulk and sequential isotopic input signals used in the IHS for the largest analysed event (event 27), as well as the isotopic composition of the stream. The patterns observed in Figure 5 serve as a general example, as these are common to most of the events, with more rainfall measured in the upper part of the catchment (VM) along with more

depleted rainfall than in the lower part $(\mathrm{VH})$; throughfall $\left(\mathrm{VT}_{\mathrm{tf}}\right)$ was also generally more 
enriched than rainfall and its volume was lower. Each event is shown in Figure A1 (Supplementary Material).

The spatial and temporal information was integrated to obtain catchment-scale isoscapes at each 5 min time step. Figure 6 shows the weighted mean catchment-scale isotopic input signal during three moments of event 27 for Scenarios 1, 2 and 3. Maps for Scenario 1 show how the isotopic composition of the input signal tends to be more enriched under forested areas and, along the elevation gradient, upper areas tend to be more depleted. Scenarios 2 and 3 reflect the elevation effect, though the input signal in Scenario 2 is more enriched than in Scenario 3 due to the effect of the forest cover. All scenarios captured temporal variability, showing different mean $\delta \mathrm{D}$ for each time step. However, maximum differences between methods occurred at the end of the event, when the incremental weighted mean had accumulated the $\delta \mathrm{D}$ differences throughout the event. In addition, comparison of temporal variability with the spatial range of $\delta \mathrm{D}$ for the seven events analysed showed that it was, in general, lower or the same as spatial variability.

When performing IHS, significant differences in pre-event water contributions were found, depending on the input signal used $\left(F_{2,32}=3.34 ; p<0.05\right)$ (Figure 7). However, for a given sampling location, no significant differences in pre-event water contributions were caused by sampling methodology (bulk or sequential collection of samples) $\left(F_{1,32}=0.08 ; p=0.77\right.$ ). Nevertheless, all runoff events were dominated by pre-event water, regardless of the hydrological conditions. Out of all the other input cases, the pre-event water contributions most similar to the catchment-scale input signal (Scenario 1) were when rainfall was sampled (bulkily or sequentially) at the lower part of the catchment (VH) (Figure 7). When using rainfall sampled at the upper part of the catchment (VM) or using Scenario 3 (deforested catchment), the contribution of pre-event water was underestimated. On the contrary, when using only 
measured throughfall $\left(\mathrm{VT}_{\mathrm{tf}}\right)$ or using Scenario 2 (forested catchment), the pre-event water contribution was generally overestimated (Figure 7).

Although mean uncertainty in pre-event water contribution between sampling locations and sampling methods was $8.5 \%$, it varied from event to event, ranging from 1 to $14 \%$ (Figure 8 ). In general, uncertainty was lower for events with little spatial variability, such as event 24 , in which the contribution of pre-event water was similar regardless of the input water used. On the other hand, uncertainties increased for events with large spatial differences, such as event 12 , and for events with similar isotopic composition between rainfall and the stream, such as event 27. Hydrographs of each event with the mean pre-event water contribution and uncertainty ranges can be seen in Figure A2 (Supplementary Material).

\section{DISCUSSION}

\subsection{Spatio-temporal variability of the input signal}

Results obtained in this study highlight the high spatio-temporal variability of rainfall amount and isotopic signature, even over short distances. The precipitation pattern in the Can Vila catchment had an elevation effect, with higher rainfall amounts accumulated in the upper part of the catchment. These rainfall differences could be attributed to a topographic effect caused by the general increase in elevation topped by a high limestone cliff that forced orographic precipitation. Simultaneously, this process may force rain-out of heavier isotopic water as a consequence of Rayleigh condensation, with steadily higher condensation levels and lower condensation temperatures (McGuire and McDonnell, 2007). This would explain why most rainfall events produced lighter rainfall at the upper part of the catchment along with higher rainfall depths. Likewise, elevation could also increase the spatial variability of rainfall due to evaporation of falling raindrops (Dansgaard, 1964). On this, Siegenthaler and Oeschger (1980) pointed out that evaporation of falling raindrops is expected to be greater in summer than in winter as it depends on the prevailing vapour pressure. Nonetheless, we did not find significant 
differences between seasons for spatial variability. The observed enrichment pattern was comparable to other patterns found in previous studies (i.e. Dansgaard, 1964; Friedman and Smith, 1970; Holdsworth et al., 1991; McGuire et al., 2005), although it corresponded to the lower range (-1.25\% per $100 \mathrm{~m}$ increase in elevation for $\delta \mathrm{D})$. One possible explanation for this is the location of the catchment, for which precipitation may originate from different moisture sources, mainly the Mediterranean and Atlantic areas (Camarero and Catalan, 1993). These different air masses have different trajectories that may also reduce the effect of elevation, as already observed by Fischer et al. (2017) in the Zwäckentobel catchment $\left(4.3 \mathrm{~km}^{2}\right)$, where rainfall enhancement and mountain shading effects for precipitation coming from different air trajectories resulted in an absence of elevation effect in its isotopic composition.

Similarly to what was previously reported by Llorens et al. (1997) for a study site close to the Can Vila catchment, pines reduced the amount of rainfall reaching the soil, especially during events of low magnitude. For events of less than $20 \mathrm{~mm}$, interception could be almost half of the incident precipitation. It was for these events when the isotopic differences between throughfall and open rainfall were higher and with higher coefficients of variation. Cayuela $e t$ al. (2018) attributed this greater variability to a greater impact of fractionation factors on unsaturated canopies. For events larger than $20 \mathrm{~mm}$, as the canopy became saturated, interception loss and isotopic differences decreased. In the same study, a higher enrichment pattern was found for samples collected under denser canopy coverage, although the spatial variability of the isotopic composition of throughfall was usually lower than its temporal variability. Similar trends were observed in a boreal Scots pine forest in northern Scotland, where greater enrichment was observed for low rainfall volumes and intensities (Soulsby et al., 2017). Therefore, the effect of throughfall in IHS may have a higher impact on runoff events responding to low rainfall amounts. In the Can Vila catchment, the highest runoff responses occurred mainly for events larger than $20 \mathrm{~mm}$. Thus, for these events the forest cover effect 
could be reduced, due to the homogenisation of the canopy's saturation, and have a relatively lower impact on the IHS results.

\subsection{Catchment-scale isotopic input signal}

Significant differences in the isotopic composition of the input signal were found between the three sampling locations, which gave rise to the following questions: which is the most representative input signal for the entire catchment? Given limitations in resources, is it better to take multiple spatially distributed bulk samples or is it better to sequentially sample one location? and is it necessary to take into account the forest effect in the input signal?

On comparing the results from the IHS performed with samples collected at single locations

(VH, VM and $\mathrm{VT}_{\mathrm{tf}}$ ) with the catchment-scale input signal for the actual land uses (Scenario 1), it was observed that the closest results to Scenario 1 were obtained when the input rainfall was collected at $\mathrm{VH}$, suggesting that $\mathrm{VH}$ was the most representative location for the entire catchment. This happened because precipitation at VH was more enriched than at VM and more depleted than at $\mathrm{VT}_{\mathrm{tf}}$. This combination eventually triggered a similar isotopic composition between $\mathrm{VH}$ and the catchment-scale input signal. As such, this does not imply that a similar location in space (i.e. near the catchment outlet) should be examined in other studies, but that the most representative location will most likely depend on the (balance between) the elevation gradient and the spatial organisation of the forested areas within the catchment.

Regarding the spatio-temporal variability of the input signal, at our study site no significant differences between bulk or sequential sampling methods were found in the IHS. Therefore, the results indicate that it may be more important to cover spatial variability than temporal variability when calculating the catchment input signal. Similar results were found in Fischer et al.(2017), who suggested that to perform robust IHS it is not only necessary to account for 
the temporal variability in the isotopic composition of rainfall, but also for its spatial variability. Therefore, multiple rain samplers should be used to characterise the isotopic composition of the input water to perform event-based IHS. Nevertheless, once the spatial variability of a catchment is known and a representative location has been found, sampling at this location at a higher resolution may have some benefits over using multiple bulk samples. For example, sequential samplers allow consecutive events to be distinguished, without the need to collect the samples immediately after the rain. In addition, if placed at different locations and under the forest cover, they allow to characterise the time intervals when the isotopic differences are most extreme. Moreover, a study by Von Freyberg et al. (2017) showed that 6 h or 12 h bulk precipitation samples failed to reflect the large isotopic variability revealed by higher sampling frequencies, and were inadequate to represent the signature of the event-water end member. Nevertheless, as they suggested, a robust IHS is also highly dependent on a correct capture of the short-term responses in the streamflow, including peak response.

Our results confirmed the importance of taking into account the effect of forested areas on the isotopic input signal, especially in events with less than $20 \mathrm{~mm}$ of rainfall depth, as forest affects both the incident volume of water reaching the soil and its isotopic composition, as shown in this catchment (Cayuela et al., 2018) and elsewhere (Kubota and Tsuboyama, 2003; Allen et al., 2017; Stockinger et al., 2017).

\subsection{Uncertainty in isotope-based hydrograph separation due to input signal selection}

Uncertainty in pre-event water contribution increased for events with high spatial variability in the input signal. Thus, the more uniform the input signal within the catchment was, the lower the uncertainty associated with the IHS. On the other hand, despite significant differences between the mean isotopic composition of rainfall and stream water, uncertainty also increased for events with varying intra-storm isotopic composition when, at a time step and location, the isotopic composition of the input signal was closer to that of the stream. Under such 
circumstances, differences between pre-event water contributions using different input signals increased. On the contrary, when bulk samples were used, this temporal variability was masked and, therefore, the uncertainty was not affected by the temporal variations of the input signal.

Uncertainty in pre-event water contribution due to the variability in the input signal ranged between 1 and $14 \%$ and varied from event to event. Uncertainty in the IHS results due to the spatio-temporal variability of the input signal was of the same order of magnitude as other sources of uncertainty, for example those related to the determination of different end members (Bazemore et al., 1994; Genereux, 1998; Uhlenbrook and Hoeg, 2003). In order to assess the uncertainty in the pre-event water contribution to runoff and to find the most representative input signal across the catchment, it is also important to account for spatial variability by sampling rainfall at different locations, including forested areas. Nevertheless, not all areas within the catchment contribute to runoff generation in the same proportion and runoffcontributing areas can expand and contract seasonally, depending on prior wet conditions (Dunne et al., 1975; Latron and Gallart, 2007). Therefore, future work to identify runoff contributing areas and their corresponding isotopic input signal could further improve our hydrological processes understanding and reduce uncertainties for IHS studies and other types of analyses that require the characterisation of isotope input.

\section{CONCLUSIONS}

The spatial variability of rainfall amount and its isotopic composition has often been overlooked in hydrological studies conducted in small headwater catchments. In this study we found that even for a small catchment $\left(<1 \mathrm{~km}^{2}\right), 83 \%$ of events during one year had more depleted rainfall in the upper part of the catchment. The analyses demonstrated the existence of an elevation effect that increased rainfall amount and, for this study's catchment, induced a mean change in $\delta \mathrm{D}$ of $-1.25 \%$ per $100 \mathrm{~m}$ increase in elevation. In addition, below forested areas, the amount of rainfall was reduced and its isotopic composition was, on average, 2.95\% more 
enriched in $\delta \mathrm{D}$ than open rainfall. Via the use of elevation and the isotopic gradient in rainfall and throughfall measured in three locations of the catchment, isoscapes were obtained to estimate a catchment-scale input signal representative of the spatio-temporal variability within the catchment. This methodology was used to identify the most representative sampling location within the catchment. Finally, while the isotope-based hydrograph separations showed that runoff was controlled by pre-event water, results could differ significantly, depending on the location of the precipitation input signal collector used. On the contrary, no significant differences were found between using bulk or sequential collectors. This suggests that, in general, resources might be best spent on capturing spatial rather than temporal variability in precipitation isotopic composition within an event. Overall, uncertainty introduced by not capturing spatio-temporal variability varied from event to event and ranged between 1 and $14 \%$.

\section{ACKNOWLEDGMENTS}

This research was supported by the projects TransHyMed (CGL2016-75957-R AEI/FEDER, UE) and MASCC-DYNAMITE (PCIN-2017-061/AEI). C. Cayuela was beneficiary of a predoctoral FPI grant (BES-2014-070609) and a pre-doctoral mobility grant (EEBB-I-17-12493). We are grateful to G. Bertran, F. Gallart, A.J. Molina, M. Moreno de las Heras and E. SánchezCosta for their support during fieldwork and data analysis. We also thank all the members of the Northern Rivers Institute where part of this study was conceived. Finally, we want to thank M. Eaude for reviewing the English. 


\section{REFERENCES}

Allen ST, Keim RF, Barnard HR, McDonnell JJ, Brooks JR. 2017. The role of stable isotopes in understanding rainfall interception processes: a review. Wiley Interdisciplinary Reviews: Water 4 (1): 1-17 DOI: 10.1002/wat2.1187

Allen ST, Kirchner JW, Goldsmith GR. 2018. Predicting spatial patterns in precipitation isotope $(\delta 2 \mathrm{H}$ and $\delta 18 \mathrm{O})$ seasonality using sinusoidal isoscapes. Geophysical Research Letters: 4859-4868 DOI: 10.1029/2018GL077458

Araguás-Araguás L, Froehlich K, Rozanski K. 2000. Deuterium and oxygen-18 isotope composition of precipitation and atmoshperic moisture. Hydrological Processes 14: 1341-1355 DOI: 10.1002/1099-1085(20000615)14:8<1341::AID-HYP983>3.0.CO;2-Z

Bazemore DE, Eshleman KN, Hollenbeck KJ. 1994. The role of soil water in stormflow generation in a forested headwater catchment: synthesis of natural tracer and hydrometric evidence. Journal of Hydrology 162 (1-2): 47-75 DOI: 10.1016/0022-1694(94)90004-3

Bowen GJ, Good SP. 2015. Incorporating water isoscapes in hydrological and water resource investigations. Wiley Interdisciplinary Reviews: Water 2: 107-119 DOI: 10.1002/wat 2.1069

Bowen GJ, West JB, Vaughn B, Dawson TE, Ehleringer JR, Fogel ML, Hobson KA, Hoogewerff J, Kendall C, Lai CT, et al. 2009. Isoscapes to Address Large- Scale Earth Science Challenges. Eos 90 (13): 109-116 DOI: 10.1029/2009EO130001

Camarero L, Catalan J. 1993. Chemistry of bulk precipitation in the central and eastern Pyrenees, northeast Spain. Atmospheric Environment 27 (A) (1): 83-94 DOI: $10.1016 / 0960-1686(93) 90073-8$

Cayuela C, Llorens P, Sánchez- Costa E, Latron J. 2018. Modification of the isotopic 
composition of rainfall by throughfall and stemflow: the case of Scots pine and Downy oak forests under Mediterranean conditions. Ecohydrology e2025 DOI: https://doi.org/10.1002/eco.2025

Celle-Jeanton H, Gonfiantini R, Travi Y, Sol B. 2004. Oxygen-18 variations of rainwater during precipitation: Application of the Rayleigh model to selected rainfalls in Southern France. Journal of Hydrology 289 (1-4): 165-177 DOI: 10.1016/j.jhydrol.2003.11.017

Dansgaard W. 1964. Stable isotopes in precipitation. Tellus 16: 436-468 DOI: http:// dx.doi.org/10.1111/j.2153-3490.1964.tb00181.x.

Dewalle DR, Swistock BR. 1994. Differences in oxygen-18 content of throughfall and rainfall in hardwood and coniferous forests. Hydrological Processes 8 (1): 75-82 DOI: 10.1002/hyp.3360080106

Dunne T, Moore TR, Taylor CH. 1975. Recognition and prediction of runoff-producing zones in humid regions. Hydrological Sciences Bulletin 20 (3): 305-327 DOI: Cited By (since 1996) 102ไrExport Date 4 April 2012

Fischer BMC, van Meerveld HJ, Seibert J. 2017. Spatial variability in the isotopic composition of rainfall in a small headwater catchment and its effect on hydrograph separation. Journal of Hydrology 547: 755-769 DOI: 10.1016/j.jhydrol.2017.01.045

Von Freyberg J, Studer B, Kirchner JW. 2017. A lab in the field: High-frequency analysis of water quality and stable isotopes in stream water and precipitation. Hydrology and Earth System Sciences 21 (3): 1721-1739 DOI: 10.5194/hess-21-1721-2017

Friedman I. 1962. Water-vapor exchange between a water droplet and its environment. Journal of Geophysical researche 67: 2761-2767 DOI: doi:10.1029/JZ067i007p02761

Friedman I, Smith G. 1970. Deuterium content of snow cores from Sierra Nevada area. Science 
169 (3944): 467-470

Genereux D. 1998. Quantifying uncertainty in tracer-based hydrograph separations. Water Resources Research 34 (4): 915-919 DOI: 10.1029/98WR00010

Girons Lopez M, Wennerström H, Nordén LÅ, Seibert J. 2015. Location and density of rain gauges for the estimation of spatial varying precipitation. Geografiska Annaler, Series A: Physical Geography 97 (1): 167-179 DOI: 10.1111/geoa.12094

Goodrich DC, Faurès JM, Woolhiser DA, Lane LJ, Sorooshian S. 1995. Measurement and analysis of small-scale convective storm rainfall variability. Journal of Hydrology 173 (14): 283-308 DOI: 10.1016/0022-1694(95)02703-R

Hargreaves GH, Samani ZA. 1982. Estimating potential evapo-transpiration. Journal of the Irrigation and Drainage Division-Asce 108: 225-230.

Hewlett JD, Hibbert AR. 1967. Factors affecting the response of small watershed to precipitation in humid areas. Forest Hydrology: 275-279 DOI: $10.1177 / 0309133309338118$

Holdsworth G, Fogarasi S, Krouse HR. 1991. Variation of the stable isotopes of water with altitude in the Saint Elias Mountains of Canada. Journal of Geophysical Research 96 (91): 7483 DOI: $10.1029 / 91 J D 00048$

Kubota T, Tsuboyama Y. 2003. Intra- and inter-storm oxygen-18 and deuterium variations of rain, throughfall, and stemflow, and two-component Hydrograph separation in a small forested catchment in Japan. Journal of Forest Research 8 (3): 179-190 DOI: $10.1007 / \mathrm{s} 10310-002-0024-9$

Latron J, Gallart F. 2007. Seasonal dynamics of runoff-contributing areas in a small mediterranean research catchment (Vallcebre, Eastern Pyrenees). Journal of Hydrology 
335: 194-206 DOI: 10.1016/j.jhydrol.2006.11.012

Latron J, Llorens P, Soler M, Poyatos R, Rubio C, Muzylo A, Martínez-Carreras N, Delgado J, Reguiés D, Catari G, et al. 2010a. Hydrology in a Mediterranean mountain environment the Vallcebre research basins (northeastern Spain). I. 20 years of investigation of hydrological dynamics. IAHS-AISH Publication 336: 38-43

Latron J, Soler M, Llorens P, Gallart F. 2008. Spatial and temporal variability of the hydrological response in a small Mediterranean research catchment (Vallcebre, Eastern Pyrenees). Hydrological Processes 22 (6): 775-787 DOI: 10.1002/hyp.6648

Latron J, Soler M, Llorens P, Nord G, Gallart F. 2010b. Hydrology in a Mediterranean mountain environment - the Vallcebre research basins (northeastern Spain). II. Rainfall runoff relationships and runoff processes. IAHS-AISH Publication 336: 151-156

Llorens P, Gallart F. 2000. A simplified method for forest water storage capacity measurement. Journal of Hydrology 240 (1): 131-144 DOI: 10.1016/S0022-1694(00)00339-5

Llorens P, Domingo F, Garcia-Estringana P, Muzylo A, Gallart F. 2014. Canopy wetness patterns in a Mediterranean deciduous stand. Journal of Hydrology 512: 254-262 DOI: 10.1016/j.jhydrol.2014.03.007

Llorens P, Gallart F, Cayuela C, Roig- Planasdemunt M, Casellas E, Molina A, Moreno de las Heras M, Bertran G, Sánchez- Costa E, Latron J. 2018. What have we learnt about Mediterranean catchment hydrology? 30 years observing hydrological processes in the Vallcebre Research Catchments. Cuadernos de Investigacion Geografica DOI: DOI10.18172/cig.3432

Llorens P, Poch R, Latron J, Gallart F. 1997. Rainfall interception by Pinus sylvestris forest patch overgrown in a Mediterranean montanious abandoned area I. Monitoring design and 
results down to the event scale. Journal of hydrology 199 (3-4): 331-345

Lyon SW, Desilets SLE, Troch PA. 2009. A tale of two isotopes: differences in hydrograph separation for a runoff event when using $\delta \mathrm{D}$ versus $\delta 180$. Hydrological Processes 23: 2095-2101 DOI: 10.1002/hyp.7326

McDonnell JJ, Beven K. 2014. Debates-The future of hydrological sciences: A (common) path forward? A call to action aimed at understanding velocities, celerities and residence time distributions of the headwater hydrograph. Water Resources Research 50: 53425350 DOI: doi:10.1002/ 2013WR015141

McDonnell JJ, Bonell M, Stewart MK, Pearce AJ. 1990. Deuterium variations in storm rainfall: Implications for stream hydrograph separation. Water resources research 26 (3): 455-458

McGuire KJ, McDonnell JJ. 2007. Stable isotope tracers in watershed hydrology (K Lajtha and W Michener, eds). Blackwell Publishing: Oxford.

McGuire KJ, McDonnell JJ. 2015. Tracer advances in catchment hydrology. Hydrological Processes 29 (25): 5135-5138 DOI: 10.1002/hyp.10740

McGuire KJ, McDonnell JJ, Weiler M, Kendall C, McGlynn BL, Welker JM, Seibert J. 2005. The role of topography on catchment-scale water residence time. Water Resources Research 41 (5): 1-14 DOI: 10.1029/2004WR003657

Pearce AJ, Stewart MK, Sklash MG. 1986. Storm runoff generation in humid headwater catchments: 1. Where does the water come from? Water Resources Research 22 (8): 1263-1272 DOI: 10.1029/WR022i008p01263

Pinder GF, Jones JF. 1969. Determination of the ground- water component of peak discharge from the chemistry of total runoff. Water Resources Research 5 (2): 438-445 DOI: 10.1029/WR005i002p00438 
Poyatos R, Latron J, Llorens P. 2003. Land use and land cover change after agricultural abandonment. Mountain Research and Development 23 (4): 362-368 DOI: 10.1659/02764741(2003)023[0362:LUALCC]2.0.CO;2

Rubio CM, Llorens P, Gallart F. 2008. Uncertainty and efficiency of pedotransfer functions for estimating water retention characteristics of soils. European Journal of Soil Science 59 (2): 339-347 DOI: 10.1111/j.1365-2389.2007.01002.x

Saxena RK. 1986. Estimation of canopy reservoir capacity and oxygen-18 fractionation in throughfall in a pine forest. Nordic Hydrology 17: 251-260

Seeger S, Weiler M. 2014. Reevaluation of transit time distributions, mean transit times and their relation to catchment topography. Hydrology and Earth System Sciences 18 (12): 4751-4771 DOI: 10.5194/hess-18-4751-2014

Seibert J, McDonnell JJ. 2002. On the dialog between experimentalist and modeler in catchment hydrology: Use of soft data for multicriteria model calibration. Water Resources Research 38 (11): 23-1-23-14 DOI: 10.1029/2001WR000978

Siegenthaler U, Oeschger H. 1980. Correlation of 180 in precipitation with temperature and altitude. Nature 285 (5763): 314-317 DOI: 10.1038/285314a0

Sklash MG, Farvolden RN, Fritz P. 1976. A conceptual model of watershed response to rainfall, developed through the use of oxygen-18 as a natural tracer. Canadian Journal of Earth Sciences 13 (5): 715-715 DOI: 10.1139/e76-076

Sklash MG, Stewart MK, Pearce AJ. 1986. Storm runoff generation in humid headwater catchments 2. A case study of hillslope and low-order stream response. Water Resources 22 (8): 1273-1282 DOI: 10.1029/WR022i008p01273

Smith GI, Friedman I, Klieforth H, Hardcastled K. 1979. Areal distribution of deuterium in 
eastern California precipitation, 1968-1969. Journal of Applied Meteorology 18 (172188) DOI: https://doi.org/10.1175/1520-0450(1979)018<0172:ADODIE>2.0.CO;2

Soulsby C, Braun H, Sprenger M, Weiler M, Tetzlaff D. 2017. Influence of forest and shrub canopies on precipitation partitioning and isotopic signatures. Hydrological Processes 31 (24): 4282-4296 DOI: 10.1002/hyp.11351

Stockinger MP, Lücke A, Vereecken H, Bogena HR. 2017. Accounting for seasonal isotopic patterns of forest canopy intercepted precipitation in streamflow modeling. Journal of Hydrology 555: 31-40 DOI: 10.1016/j.jhydrol.2017.10.003

Uhlenbrook S, Hoeg S. 2003. Quantifying uncertainties in tracer-based hydrograph separations: A case study for two-, three- and five-component hydrograph separations in a mountainous catchment. Hydrological Processes 17 (2): 431-453 DOI: 10.1002/hyp.1134

Vieux BE. 2016. Distributed precipitation estimation. In Distributed Hydrologic Modeling Using GIS, Water Science and Technology Library (ed.).Springer: Dordrecht; 133-163. DOI: $10.1007 / 978-94-024-0930-7$

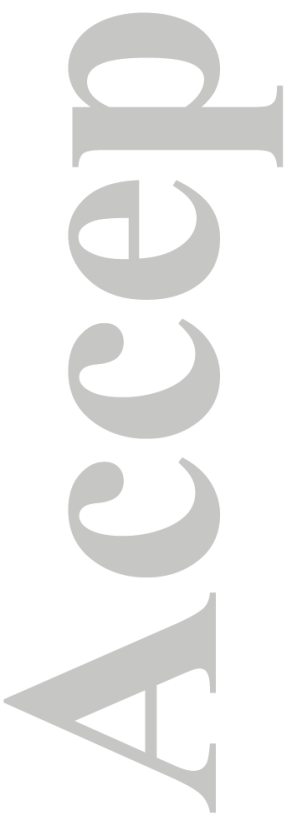


Table 1. Rainfall and hydrological characteristics of the seven runoff events used for IHS. The last row of the table shows the ranges measured during all events and runoff responses (larger than $0.003 \mathrm{~mm}$ of runoff) that occurred during the period studied. Rainfall intensity is calculated as maximum intensity in 30 minutes. Response time is the time interval between the peak flow and the time when half the precipitation has fallen. Specific discharge increment is the difference between peak-flow discharge and base-flow discharge.

\begin{tabular}{rrrrrrrr}
\hline Event & $\begin{array}{c}\text { Rain } \\
(\mathrm{mm})\end{array}$ & $\begin{array}{c}\text { Intensity } \\
(\mathrm{max} 30) \\
\left(\mathrm{mm} \mathrm{h}^{-1}\right)\end{array}$ & $\begin{array}{c}\text { Runoff } \\
\text { duration } \\
\text { (hours })\end{array}$ & $\begin{array}{c}\text { Response } \\
\text { time } \\
\text { (hours })\end{array}$ & $\begin{array}{c}\text { Runoff } \\
(\mathrm{mm})\end{array}$ & $\begin{array}{c}\text { Specific } \\
\text { discharge } \\
\text { increment }(1 \\
\left.\mathrm{s}^{-1} \mathrm{~km}^{-2}\right)\end{array}$ & $\begin{array}{c}\text { Stormflow } \\
\text { coefficient } \\
(\%)\end{array}$ \\
\hline 4 & 11.6 & 8.3 & 24.0 & 1.3 & 1.7 & 48.2 & 4.5 \\
12 & 27.4 & 14.2 & 37.5 & 6.2 & 0.6 & 6.8 & 2.2 \\
14 & 48.5 & 16.2 & 26.0 & 26.6 & 8.9 & 51.7 & 14.5 \\
23 & 23.7 & 9.3 & 8.5 & 73.5 & 4.5 & 20.5 & 11.5 \\
24 & 77.4 & 10.7 & 65.1 & 2.1 & 32.4 & 465.7 & 39.6 \\
25 & 35.9 & 8.7 & 32.6 & 4.2 & 5.0 & 66.3 & 13.8 \\
27 & 120.6 & 19.6 & 83.3 & 9.3 & 82.3 & 1111.3 & 59.7 \\
\hline & $3-129$ & $2-71$ & $8.5-83.3$ & $0.9-73.5$ & $0.6-82.3$ & $6.8-2620.0$ & $2.2-59.7$ \\
\hline
\end{tabular}

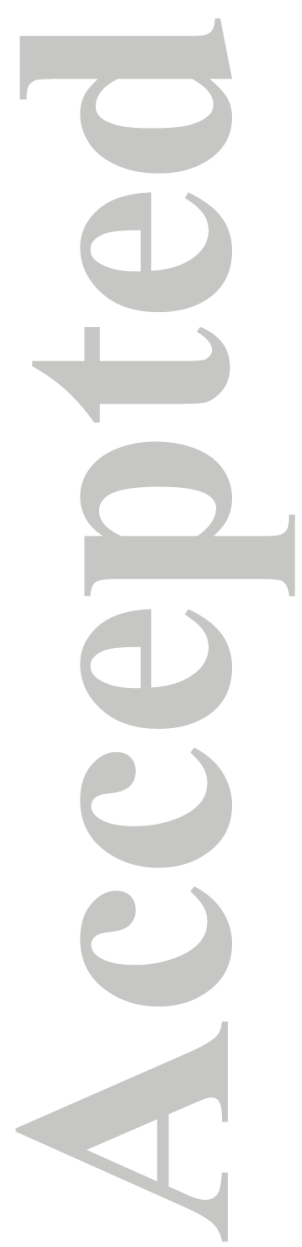


a)

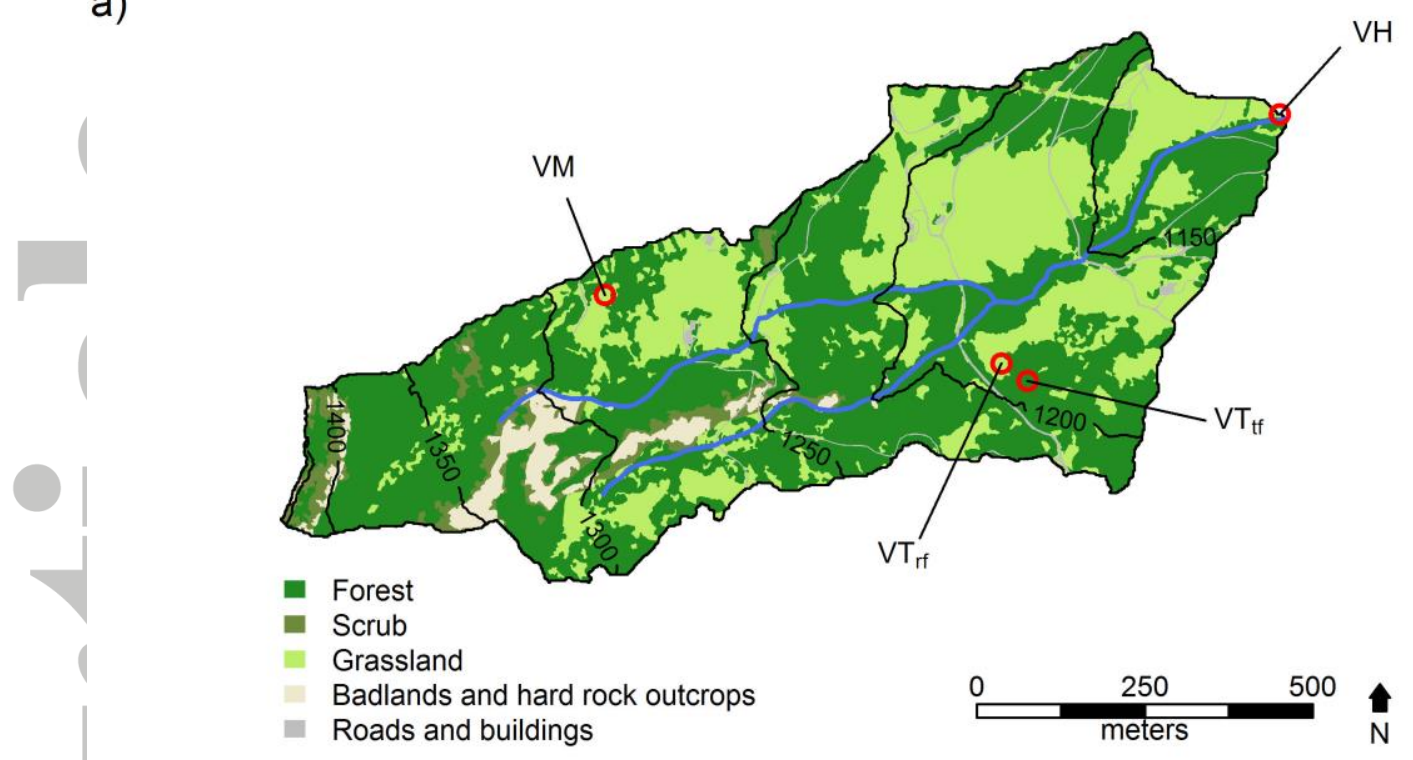

b)

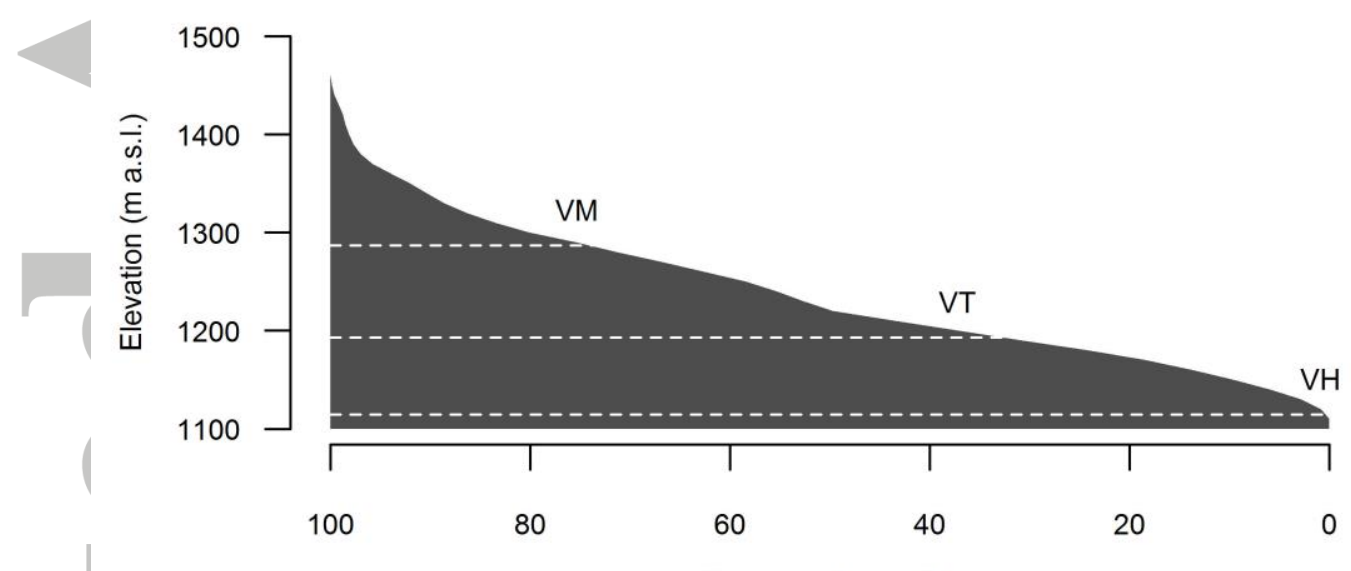

Catchment area (\%)

Figure 1. (a) Land use map of the Can Vila catchment. Red circles indicate the sampling locations for rainfall (rf): VM (1,287 $\mathrm{m}$ a.s.l.), $\mathrm{VT}_{\mathrm{rf}}(1,193 \mathrm{~m}$ a.s.l.) and $\mathrm{VH}(1,115 \mathrm{~m}$ a.s.l.); and for throughfall (tf): $\mathrm{VT}_{\mathrm{tf}}$ (b) Elevations represented by the catchment area. Dashed lines indicate the elevation of the sampling locations. 

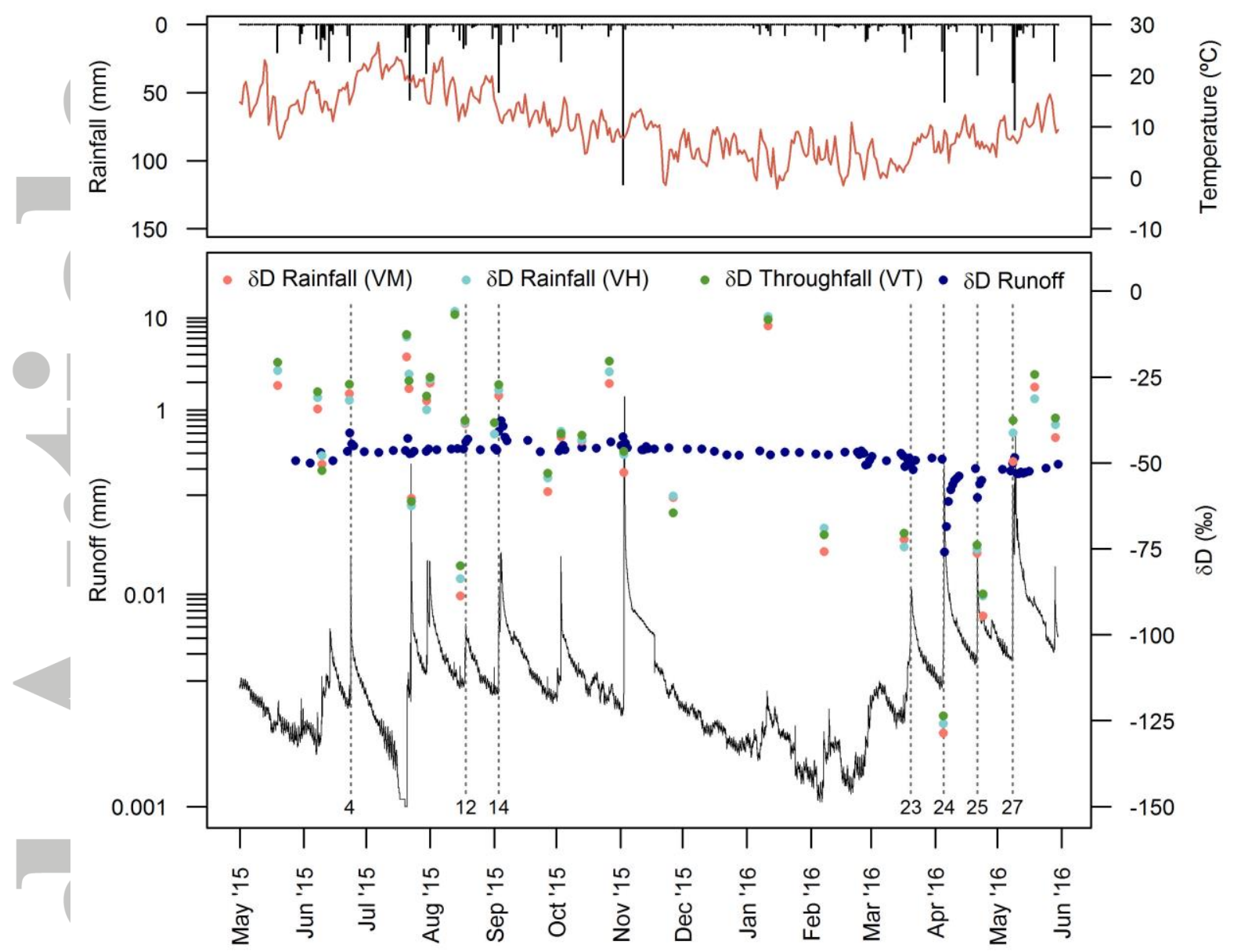

Figure 2. Daily rainfall and temperature time-series during the studied period (top). Daily runoff and isotopic composition $(\delta \mathrm{D})$ of rainfall, throughfall and runoff (bottom). Dashed lines indicate the runoff events analysed with IHS. 


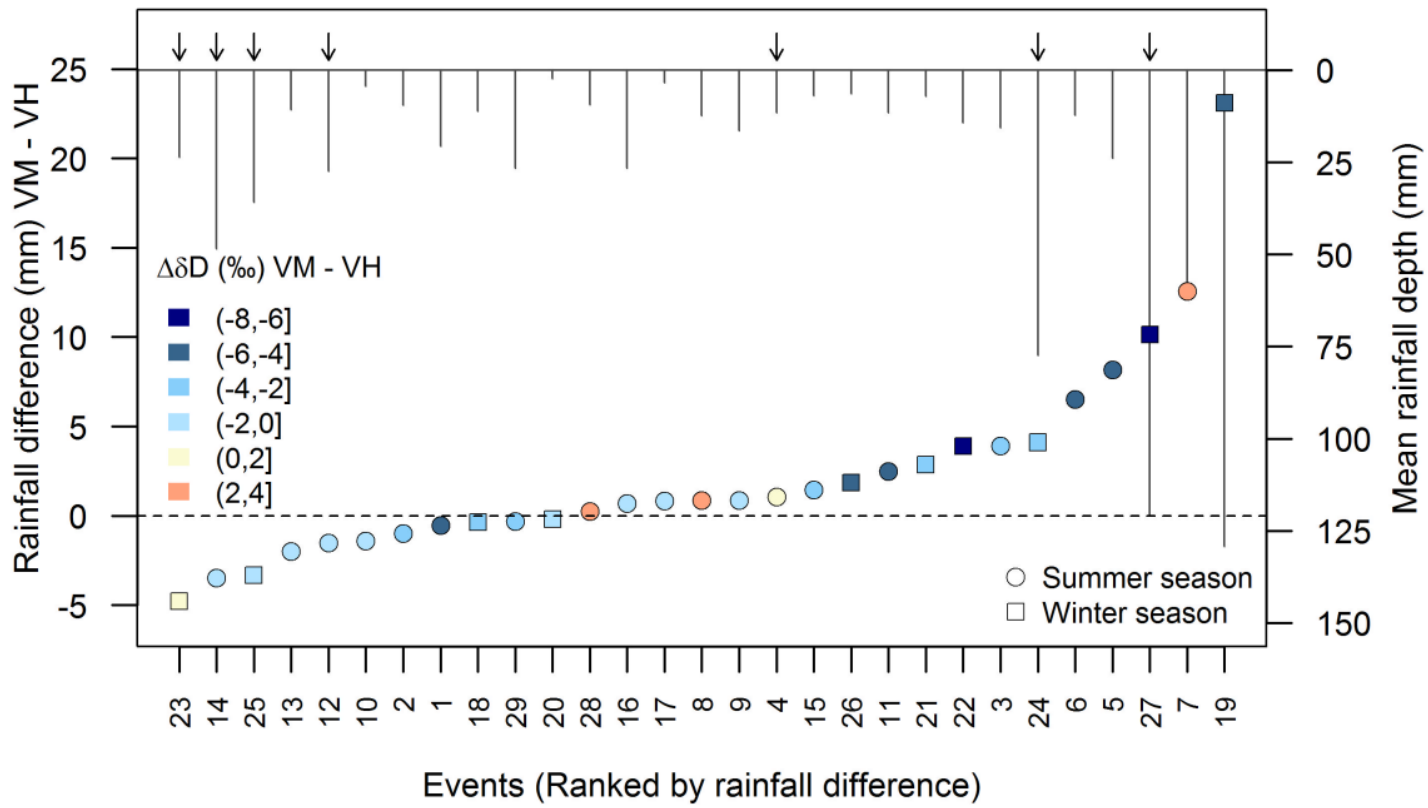

Figure 3. Rainfall isotopic differences $(\Delta \delta \mathrm{D})$ in relation to rainfall amount differences. Events are ranked by increasing rainfall amount differences between the upper (VM) and the lower (VH) parts of the catchment. Rainfall events with more depleted isotopic composition in VM than in $\mathrm{VH}$ are in blue; and those more enriched in VM than in $\mathrm{VH}$ are in red. Catchment mean event rainfall is represented by vertical lines. Circles and squares indicate the season and arrows indicate the events with runoff responses analysed by IHS. 


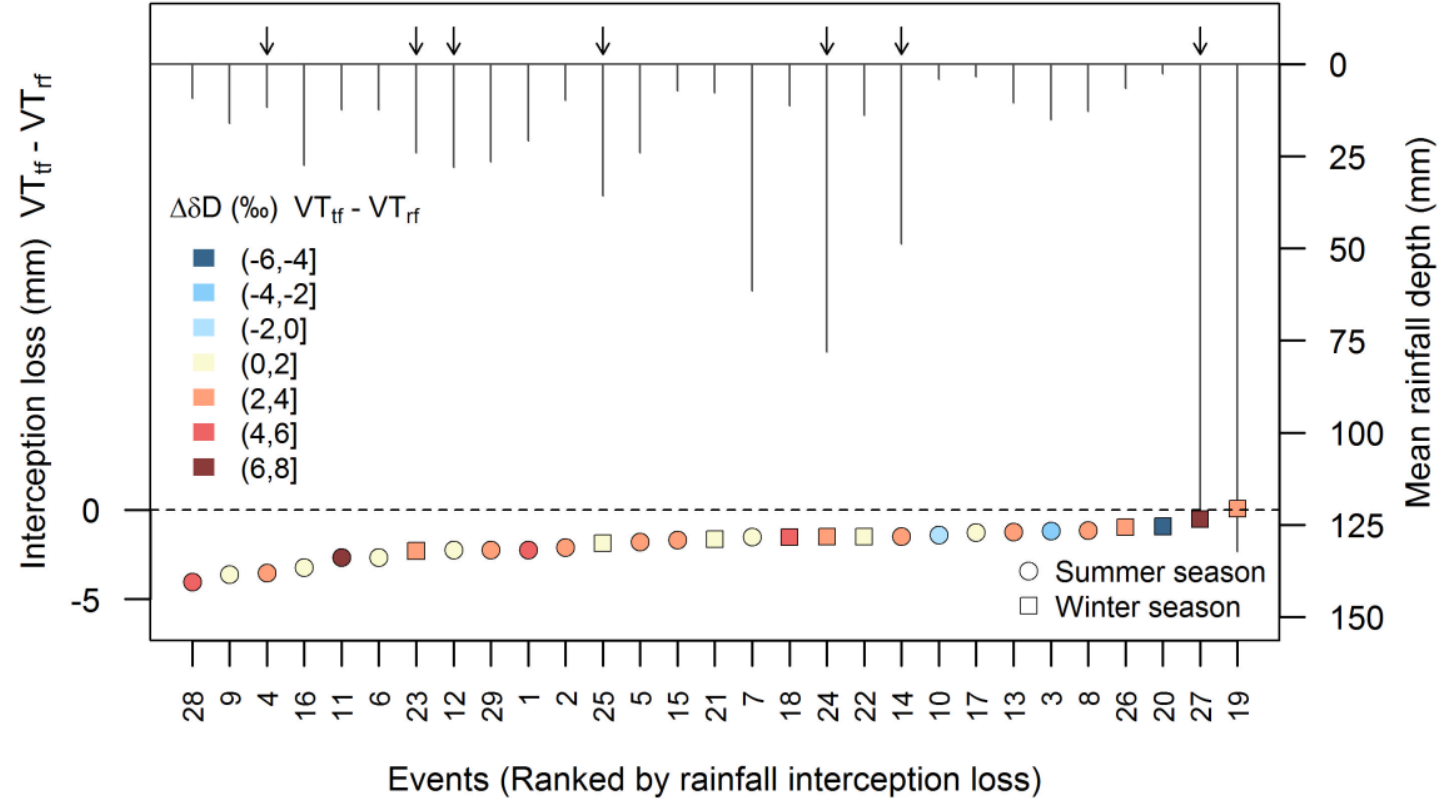

Figure 4. Rainfall isotopic differences $(\Delta \delta \mathrm{D})$ in relation to rainfall interception loss. Events are ranked by increasing rainfall interception (differences between throughfall $\left(\mathrm{VT}_{\mathrm{tf}}\right)$ and rainfall $\left.\left(\mathrm{VT}_{\mathrm{rf}}\right)\right)$. Rainfall events with more depleted isotopic composition in throughfall than in rainfall are in blue; and those more enriched in throughfall than in rainfall are in red. Catchment mean event rainfall is represented by vertical lines. Circles and squares indicate the season and arrows indicate the events with runoff responses analysed by IHS. 

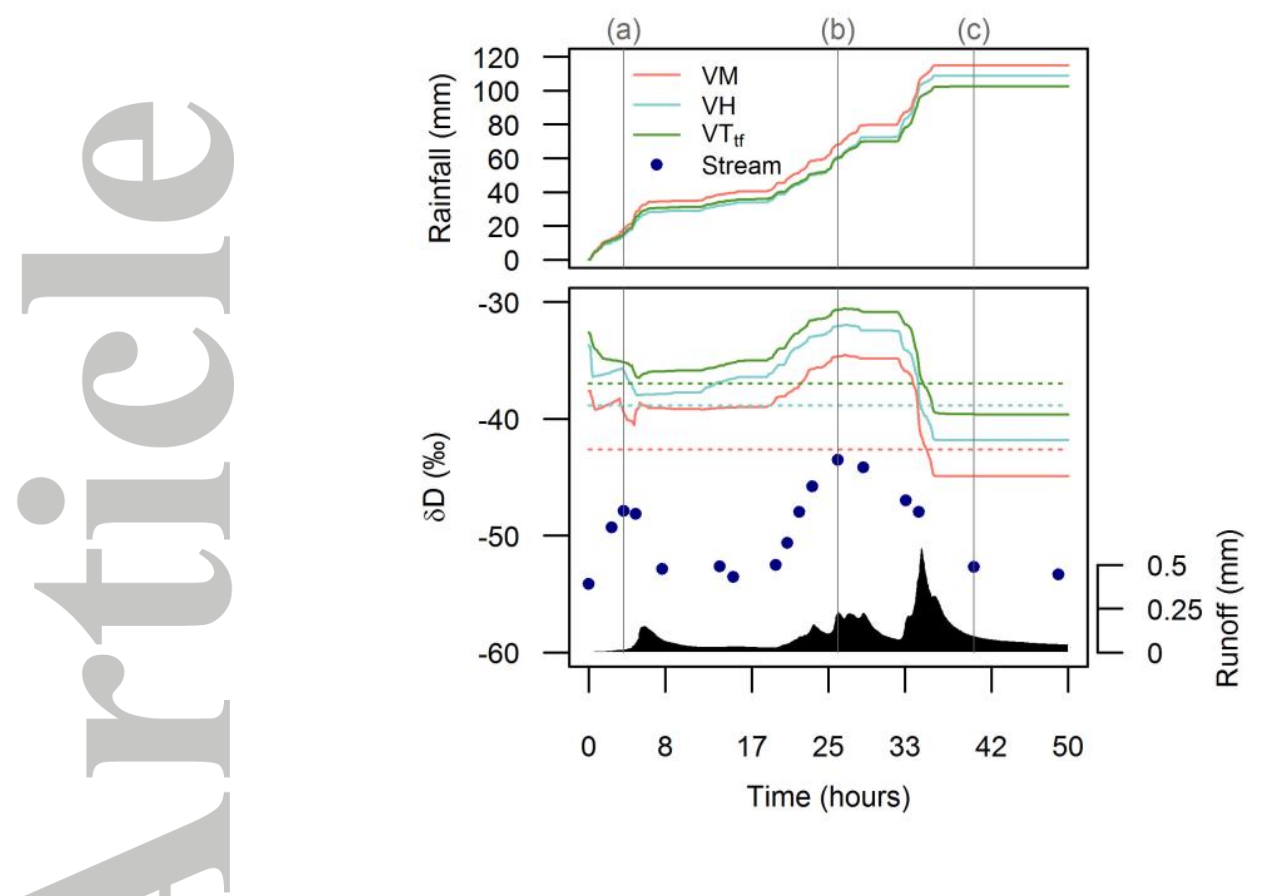

Figure 5. Cumulative rainfall in $\mathrm{VM}$ and $\mathrm{VH}$ along with cumulative throughfall in $\mathrm{VT}_{\mathrm{tf}}$ throughout event 27 (top). Runoff and isotopic composition ( $\delta \mathrm{D})$, in $\mathrm{VM}, \mathrm{VT}_{\mathrm{tf}}, \mathrm{VH}$ and in the stream during the event (bottom). Continuous lines represent volume-weighted incremental mean isotopy (from sequential samples) and dashed lines represent the mean value (from bulk samples). Vertical lines ( $\mathrm{a}, \mathrm{b}$ and $\mathrm{c}$ ) refer to three moments of the event, for which the spatiotemporal yariability of the catchment-scale input signal is shown in Figure 6. 
Scenario 1

(a)

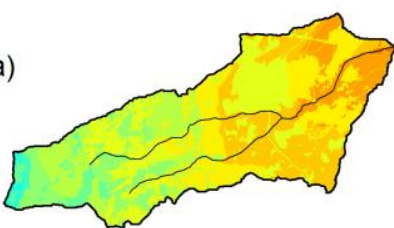

mean $\delta \mathrm{D}=-37.2 \%$

(b)

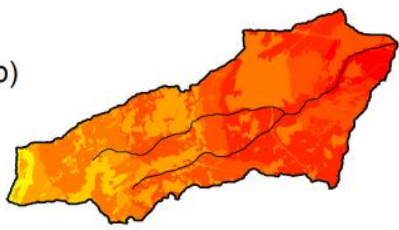

mean $\delta \mathrm{D}=-32.9 \%$

(c)

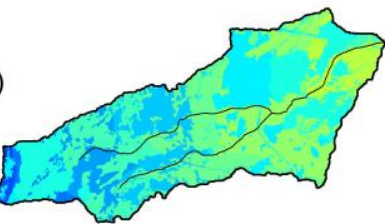

mean $\delta \mathrm{D}=-41.9 \%$
Scenario 2

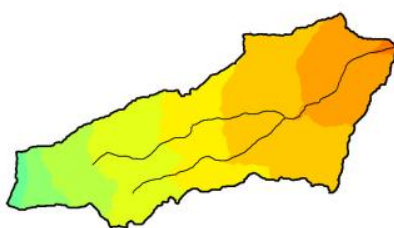

mean $\delta \mathrm{D}=-36.4 \%$

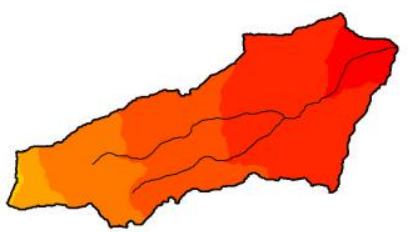

mean $\delta \mathrm{D}=-32.2 \%$

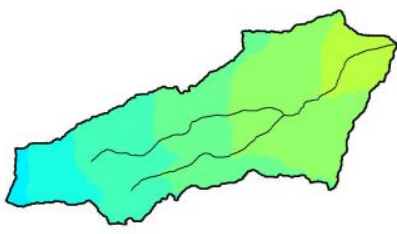

mean $\delta \mathrm{D}=-40.4 \%$ o

$\delta \mathrm{D}(\% 0)$
Scenario 3

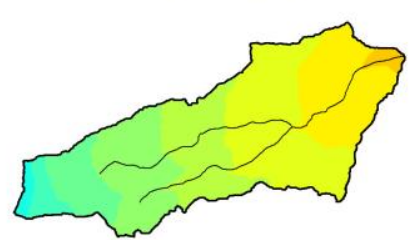

mean $\delta \mathrm{D}=-38.3 \%$

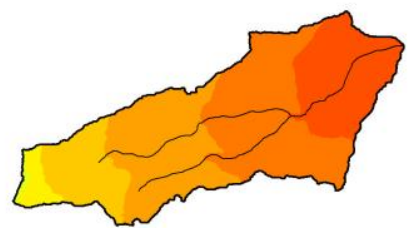

mean $\delta \mathrm{D}=-33.9 \%$

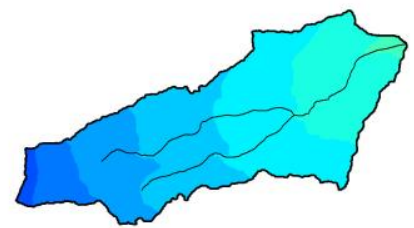

mean $\delta \mathrm{D}=-44.0 \%$

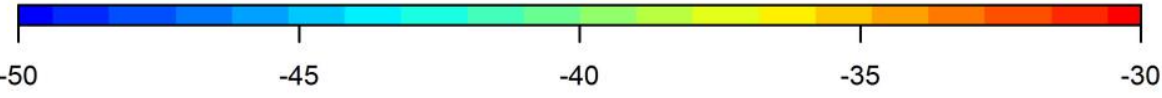

Figure 6. Maps of the catchment-scale input signal during three moments of event 27 (a, b and c). Scenario 1 represents the isotopic input signal for the catchment with the current land use information; Scenario 2 represents the isotopic input signal for a hypothetical catchment completely covered by forest; and Scenario 3 represents the isotopic input signal for a hypothetical catchment completely covered by grassland. 


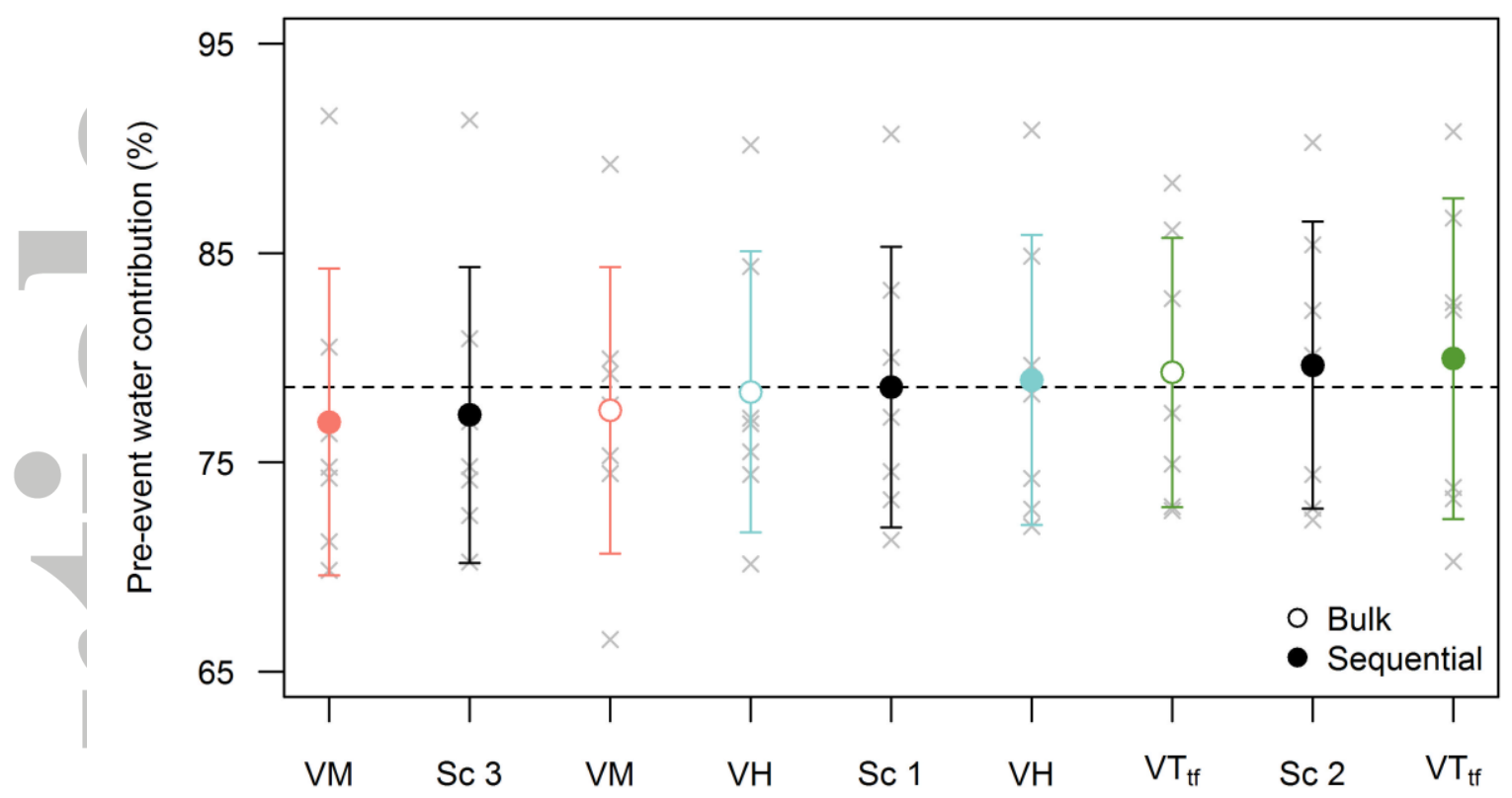

Figure 7. Comparison of the mean pre-event water contribution (for the 7 events analysed) as function of the input signal used in the isotope-based hydrograph separation ("Sc" on the $\mathrm{x}$ axis is the abbreviation of "Scenario"). Vertical lines indicate the standard deviation of the mean pre-event water contribution and grey crosses represent the value of pre-event water contribution for each event. The dashed line represents the pre-event water contribution, using the catchment-scale input signal for Scenario 1 (58\% of forest). 


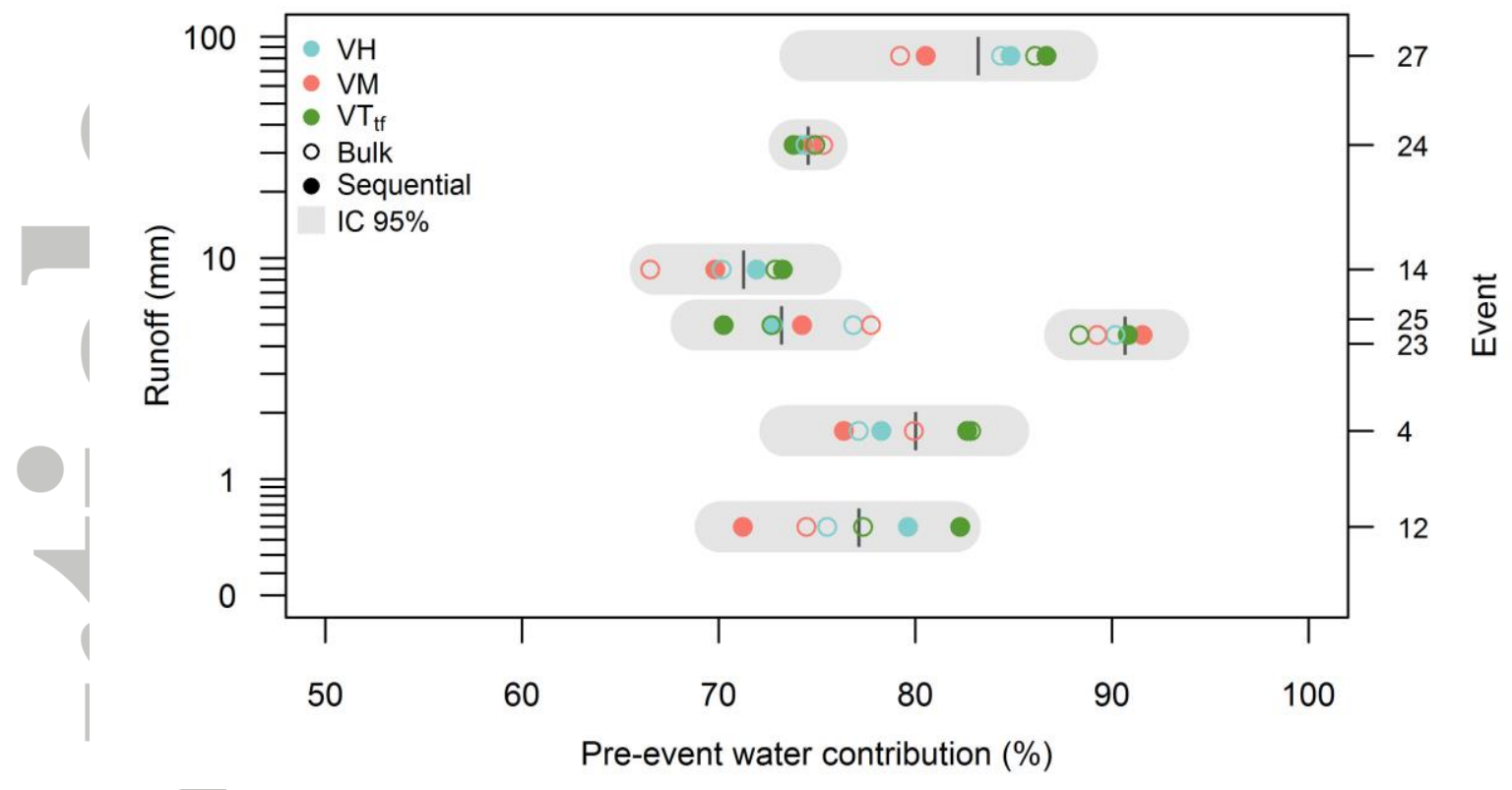

Figure 8. Pre-event water contribution for the seven events analysed. Vertical black lines and grey areas represent the pre-event water contribution for Scenario 1 with a $95 \%$ confidence interval. 